\title{
ENIS Model of Environmental Education for Elementary School Students in Japan
}

\author{
Budi Mulyadi* \\ Faculty of Humanities, Diponegoro University
}

\begin{abstract}
Japan is a country whose people have a high awareness of the importance of environmental preservation. The environment in Japan can be maintained well not apart from the cooperation between the government and the community together to preserve and protect the surrounding environment. One of the keys to Japan's success in protecting the environment is the consistent and dynamic implementation of environmental education since elementary school age. Environmental education in primary schools in Japan is taught directly through experiments and direct observation in the surrounding environment. Environmental education in primary schools in Japan is associated with several subjects, one of which is the subject of Natural Sciences (rika) and Social Sciences (shakai). Environmental education is also taught through integrated study activities (sougotekina gakushu), through efforts to maintain cleanliness together, through assignments during the summer holidays. The model of environmental education is implemented consistently and with full awareness by elementary school managers in Japan and their students so as to produce students who have a high awareness of the importance of protecting the environment.
\end{abstract}

Keywords. environment, Japan, children, elementary school

\section{Introduction}

Environmental education is very important nowadays along with the decreasing public awareness of the importance of the environment to ensure the sustainability of human life in this world. The environmental damage that occurs everywhere is one example due to the lack of public awareness of the environment. The lack of public awareness is caused by the lack of education about the environment. Pratomo in his book explained that environmental education is an educational program to foster children or students to have a rational understanding, awareness, attitude, and behavior about the mutual influence between the population and the environment in various aspects of human life [1].

The environment is part of today's global problem. It is related to human security when every country is now concerned with environmental issues for the future of humanity. The emergence of environmental problems is responded to by making many programs related to

\footnotetext{
*Correspondingauthor: budi.mulyadi09@gmail.com
} 
environmental preservation and education. Environmental education is important not only to educate people about the environment but it is part of investing in the future [2]. Environmental education aims to make people aware of the environment. Environmental awareness is defined as it is expected to be able to build the character of humans who love their environment.

Japan is a country that is very concerned about environmental education. Environmental education in Japan is implemented starting from early childhood schools to higher education. Not only informal education institutions but non-formal institutions are also environmental education implemented so that we can see Japan as one of the countries in the world that have succeeded in preserving the environment. Japan is a very clean country because its people have a very high awareness of the importance of a healthy environment.

Subarkah in his book entitled Extraordinary Ideas from the Success of the Japanese Nation explained, in Japan, no one is littering. Their extraordinary discipline makes their obedience to the rules so extraordinary. For example, when smokers in Japan walk in the park, they will carry ashtrays in their pockets to get rid of their ashes and cigarette butts. If they find trash, they will throw the ashtray in the trash. That is a small example that is extraordinary to appreciate small details in order to respect the environment [3].

Murni Ramli in her book entitled Being a Character and Cultured Person in Japan explains Japanese awareness about the importance of the environment for them. In addition to aesthetics, the Japanese also have a spirit that enjoys cleanliness. Japanese houses even though it looks small but arranged with practicality in the cleaning process. Public facilities are always equipped with a variety of garbage boxes to enable residents to directly sort out their waste. If they do not find a trash can, they will carry it along until they find a trash can [4].

Japan's high awareness of the environment is inseparable from the role of the Japanese government in educating its people to have a high awareness of the surrounding environment. The Japanese government collaborates with formal and non-formal educational institutions to create an ideal model of environmental education for the community starting from environmental education for elementary school students, junior high schools, senior high schools to universities. This is consistent with what was written by Kouji Amemiya and Darryl Macer in a paper entitled Environmental Education and Environmental Behavior in Japanese Students published in Eubios Journal of Asian and International Bioethics 9. Kouji explained that one point of view that must be considered in environmental education is that environmental education must be carried out at all ages, according to each stage of development. Especially, in the teenage stage, recognition of the natural environment and stimulation of children's sensitivity to the environment must receive attention. Realizing this, the Japanese government has long tried to create a model of environmental education starting from the level of early childhood to the level of college. Toshiya Kodama in his paper entitled Environmental Education in Formal Education in Japan explained that since the 2000s, schools in Japan have developed various approaches to environmental education, reflecting the characteristics of each region. In general, environmental education has been carried out in accordance with the guiding principles of the Teacher's Guide to Environmental Education [5]. From Toshiya Kodama's explanation, we can know that in Japan environmental education has become an important part of the education curriculum so that special guidelines are made that contain principles that guide teachers to teach environmental education.

One of the interesting things in the model of environmental education in Japan is that they educate the environment starting from childhood. The Japanese government realizes that environmental education must be instilled starting from childhood so that from childhood they are accustomed to love and care for the environment. Loving nature and the environment is one of the characters that is instilled in the souls of children in Japan and is 
included in the education program at school. Children are likened to blank paper that has not been filled with anything so that character education taught to children to love the environment will be easily embedded in their minds and imprinted into adulthood. Loving nature and the environment is one of the characters that is instilled in the souls of children in Japan and is included in the education program at school. Children are likened to blank paper that has not been filled with anything so that character education taught to children to love the environment will be easily embedded in their minds and imprinted intoadulthood.

There are many examples of environmental education models implemented in primary schools in Japan were through the environmental education model the character of students who have a high awareness of the environment is formed. For example, elementary school children in Japan learn about the environment by entering directly into nature, observing, and studying the surrounding natural environment. This activity is usually integrated with one particular subject. By entering directly into nature students can learn and observe the environment directly and they can learn about the importance of protecting the environment. Environmental education in Japan takes precedence. The implementation of environmental education starts with early childhood education.

In her book Murni Ramli explained that to educate elementary school children have a high sense of concern for the environment, in the Elementary School curriculum in Japan there are three themes that are incorporated into life-related subjects called seikatsu. The three are:

1. The theme of changing seasons and the traditions that follow. Through this theme, children learn about nature and their environment, annual celebrations, and practice to arrange celebrations with children's unique model. They understand the changing seasons and can prepare themselves to be able to pass different seasons.

2. The theme of the game with natural materials and objects around. Through this theme, children learn about how children play in groups, friendship relationships, and agreement on the rules of play and use nature and things around to make interesting games.

3. Themes about raising animals and plants. Through this theme, children learn attitudes and good treatment for living beings and do not have a tendency to despair [6].

For environmental hygiene issues, elementary school students in Japan have been educated to love environmental cleanliness by implementing school regulations such as, at school after lunch, students are given the task of cleaning trash and dust. Students are divided into groups. Each group consists of four people from different classes. There are groups in charge of cleaning stairs, toilets, classes, and others. After finishing cleaning, the senior will ask about the work of their junior [7].

From the description above, the purpose of this study is to find out more about the environmental education model implemented in elementary schools in Japan in the hope that it can become an example of the environmental education model in Indonesia.

\section{Research Method}

This research is a combination of library research and field research. Literature studies are used to make an analysis of the problem being studied. While field research is conducted when researchers have the opportunity to go to Japan to conduct educational training activities from The Japan Foundation. When in Japan researchers have the opportunity to visit several elementary schools and can observe directly and ask about the model of environmental education to students and primary school teachers in Japan. 


\section{Discussion}

This research is a combination of library research and field research. Literature studies are used to make an analysis of the problem being studied. While field research is conducted when researchers have the opportunity to go to Japan to conduct educational training activities from The Japan Foundation. When in Japan researchers have the opportunity to visit several elementary schools and can observe directly and ask about the model of environmental education to students and primary school teachers in Japan.

\subsection{Definition of environmental education}

Education is the process of changing students' identities to become more advanced. According to experts, there are several definitions that explore the definition of education itself, including according to $\mathrm{H}$. Horne, education is a process that occurs continuously (eternal) of higher adjustment for humans who have developed physically and mentally free and aware of God manifested in the natural, intellectual, emotional and humanitarian environment [8].

The definition of the environment according to some experts is a unity between all living and non-living things which include various environmental elements and their benefits as well as the interaction of species and all-natural resources. So in general environmental education can be interpreted as an effort to change the behavior and attitudes carried out by various parties or elements of society that aim to increase knowledge, skills, and awareness of the community about environmental values and environmental issues that ultimately can move the community to act actively. in efforts to preserve and save the environment for the benefit of present and future generations. Environmental education studies environmental problems, especially problems and management of pollution, environmental damage, and resources and conservation [9].

\subsection{Environmental Education in Japan}

The beginning of the emergence of awareness about the importance of environmental education in Japan began when the emergence of public health problems in the 1950s. That year a disease called minamata and itaiitai emerged [10]. Watanabe in an article written by Kouji Amemiya explained that responding to the phenomenon of the emergence of the disease the Japanese government imposed rules whose purpose was to adjust between national health and industrial development because there was not enough progress in solving this problem. Under such conditions, public safety education is practiced, by many claims there is no clear concept of environmental education [11].

In 1993 the Basic Environment Act was enacted and in 1994 the Kankyou Kihon Keikaku was drafted. This Basic Environmental Law states that the Ministry of Science and Culture Education (MESC) has published three books with the title Environmental Education Teaching Materials (Kankyou Kyouiku Sidou Siryou) for junior and senior high schools in 1991, and for primary schools in 1992.

The concept of environmental education in Japan often refers to these books which are presented as national education policies. The books discuss environmental preservation, the need for environmental education, environmental education objectives, and basic ways of thinking about environmental education.

The book states that the purpose of environmental education is to have an awareness of the environment, to understand human responsibilities and their role in the environment, and to develop attitudes to participate in environmental preservation, and the ability to solve environmental problems. They discussed five issues regarding the point of view in 
terms of environmental education. The five points of view are as follows; (1) Environmental education must be carried out at the family, school, and regional levels. (2) Environmental education must be carried out at all ages, according to each stage of development. Especially, in the teenage stage, touching nature must be highlighted, and stimulation of children's sensitivity to the environment. (3) Environmental education must be carried out not only to gain knowledge but also to learn skills and develop attitudes. (4) In environmental education, people develop the ability to decide their will based on an environmentally friendly lifestyle. (5) In environmental education, people learn that environmental problems around them are connected to global environmental problems [12].

\subsection{Environmental Education Model for Elementary School student in Japan}

As explained in the introduction chapter, Japan educates its citizens about environmental education starting from an early age. Japan realizes that growing public awareness to protect and preserve the environment cannot be done instantly. Japan started from childhood and started from the smallest things.

The followings are a few examples of environmental education models implemented in primary schools in Japan that have proven to be effective in raising student awareness of the importance of the environment.

1. Environmental education is taught directly through experimentation and direct observation in the surrounding environment. Children are allowed to touch directly with their natural surroundings. They are allowed to think according to their reasoning, open creative and proactive, not through explaining theories in class, working on difficult questions at worksheets and memorizing lots at home.

2. Environmental education in primary schools in Japan is associated with several subjects one of which is the subject of Natural Sciences (RIKA). When learning about plants, children are invited by the teachers to directly plant plants in school through gardening activities [13]. The teacher instills a strong understanding to students that trees are important elements that cannot be separated from human life so humans must maintain and preserve them. To establish a harmonious relationship with the surrounding nature, since the first grade of elementary school, Japanese children learn subjects called seikatsu, namely the study of life sciences. This lesson aims to train children to be independent and skilled in living their lives. One of the targets of this subject is children can recognize their relationship with nature. It is hoped that by knowing the surrounding nature, the spirit will grow to love the surrounding environment so that children will become humans who can preserve the natural environment from damage. Through lessons as children are told by their teachers to play in the park near the school, the children learn about nature. During the summer they are given the task of playing in the park near the school. After that, they presented their experiences playing in the park. There are children who present about insects. They show the insects they catch, explain about the types of insects, the benefits of insects in life. Aside from going through Natural Science subjects, children also learn about the environment and their impact on life through Social Science lessons that were originally taught in third grade. Through this lesson, the children surveyed rivers and water distillations where river water containing household waste such as soap was processed to be clean again.

3. Environmental education is also taught through integrated study activities (sougotekina gakushu). Through this activity, children are trained to think critically in finding a problem, including environmental problems. An example of this activity is the teacher conducting interviews with the community around the school. Then according to each student's interests, they determine who and what field is being interviewed. For example, interviewing home-scale bread entrepreneurs near schools. They asked the 
process of making bread, how to make it, how to process the waste bread. From the baker's explanation, the children will learn the waste from the bread is processed so it does not pollute the surrounding environment.

4. Environmental education is taught through efforts to maintain cleanliness together. For fostering a love of environmental cleanliness, elementary school children in Japan have begun to be introduced to the varieties of waste by type. Schools also have different trash cans for different types of garbage [14]. Such as rubbish that can be burned, and cannot be burned, garbage leftover from food scraps, can garbage, glass garbage. After lunch, each child is required to clean up his own trash. At the picnic, each child is required to bring their own garbage bags to store their own garbage during the trip and bring the garbage home. They use the afternoon break to work together to clean the school. Unlike in Indonesia, where cleaning tasks only cover the classroom and once a week for each student. In Japan, cleaning the school is done every day for all students. The location he cleared was not only in the classroom but in the whole school. Cleaning equipment in the form of mops to clean each school brought by students from home. Each child is required to bring three to five mops to be left in class. During the long summer holiday, parents, principals, and all school staff work together to clean the school. With all the students cleaning the school, primary schools in Japan do not have cleaning services like schools in Indonesia. Keeping the school clean is their shared responsibility.

5. Environmental education is taught through assignments during the summer holidays. During the long summer holidays, elementary school children in Japan are given the task of planting plant seeds at home. Each student gets plant seeds, plastic pots, fertilizer, and soil from the school. All materials are then taken home and taken care of every day until they grow into plants, flowers, and fruits. The fruit is then harvested and counted the number of seeds produced. All observational data are recorded in a form received from the school. Then the seeds from the fruit are collected at school, used as seeds for their juniors next year. The activity of planting seeds at home is one of the models of environmental education in which elementary school students from childhood have been taught to love the environment by planting and caring for plants well so that the balance of nature and the environment is maintained.

6. During the long summer vacation, the school urges parents to encourage as many children as possible to carry out positive activities related to nature such as gardening, trips to nature such as rivers, seas, and lakes. It is hoped that this activity will lead to children's love for the environment.

7. To foster a love for plants and animals, every elementary school in Japan has plants and animals that are kept together. When the harvest arrives, vegetables and fruits are cooked together, sometimes students' parents are also invited to taste the harvest. For rural Japan, usually, there are still many rice fields. This is used by teachers to ask children to enter directly into the fields and try to plant rice. Some schools even have their own gardens and rice fields, although not too broad. Teachers and children who plant and care for them. Through this activity, children are taught to love and to care for the surrounding environment. 


\section{Conclusion}

Japan is a very creative and innovative country in various fields. In terms of environmental education, even Japan has a very special and unique way. Japan considers that environmental education must start from the age of children. Realizing this, elementary schools in Japan are trying to create an attractive model of environmental education that refers to the goals of environmental education, namely to have an awareness of the environment, to understand human responsibilities and their role in the environment, and to develop attitudes to participate in environmental preservation, and the ability to solve environmental problems. Through various kinds of efforts, one of them through the model of environmental education implemented in elementary schools, Japan has succeeded in becoming one of the countries in the world that has high awareness, understanding, and responsible citizens can develop and participate and are able to solve environmental problems. Things like this are what Indonesia must emulate so that Indonesia can be like Japan in terms of protecting and preserving the natural environment from damage.

\section{References}

1. Pratomo, Suko, Model Pembelajaran Tematik dalam Pendidikan Lingkungan (PLH) di Sekolah Dasar, Journal of Basic Education No. 112009 Pages 8-15, Bandung: Resposition UPI.EDU (2009)

2. T D Effendi, Local Wisdom-based Environmental Education through Kikigaki Method: Japan Experience and Lesson for Indonesia, IOP Conference Series: Earth and Environmental Science Sci. 239 012038, University of Muhammadiyah Malang (2019)

3. Subarkah, Imam, Ilham-Ilham Dahsyat dari Kesuksesan Bangsa Jepang, Yogyakarta: Flashbook (2013)

4. Ramli, Murni, Menjadi Orang berkarakter dan Berbudaya Jepang, Yogyakarta: Manggar Media (2018)

5. Kodama, Toshiya, Environmental Education in Formal Education in Japan, Japanese Journal of Environmental Education VOL. 26-4 (2017)

6. Ramli, Murni, Menjadi Orang berkarakter dan Berbudaya Jepang, Yogyakarta: Manggar Media (2018)

7. Herianti, Yanti, Pendidikan Lingkungan, Tangerang Selatan: IEPF (2016)

8. Listyarti, Retno, Pendidikan Karakter dalam Metode Aktif, Inovatif dan Kreatif. Jakarta: Esensi Erlangga (2012)

9. Setyowati, Dewi Liesnoor, Pendidikan Lingkungan Hidup, Buku Ajar, Semarang: Unnes (2014)

10. M. Numata, Howto Understandand Implement Environmental Education in Japanese High Schools, Chiba University.

11. Kouji Amemiya \& Darryl Macer, Environmental education and environmental behaviour in Japanese students, Eubios Journal of Asian and International Bioethics 9 109-115, Institute of Biological Sciences, University of Tsukuba (1999)

12. Kouji Amemiya \& Darryl Macer, Environmental education and environmental behaviour in Japanese students, Eubios Journal of Asian and International Bioethics 9 109-115, Institute of Biological Sciences, University of Tsukuba (1999)

13. Juliandi, Putri. Pendidikan Anak Ala Jepang, Jakarta: Gramedia (2014)

14. Setiana, Sony Mulyawan, Peranan Masyarakat Jepang Dalam Pengelolaan Sampah Rumah Tangga, Artikel Prosiding Seminar Internasional, Yogyakarta: UGM (2014) 